\title{
Solomon Islands
}

National Cancer Institute

\section{Source}

National Cancer Institute. Solomon Islands. NCI Thesaurus. Code C17148.

A group of islands in the South Pacific Ocean, east of Papua New Guinea. 